American Journal of Biotechnology and Biochemistry 3 (1): 24-32, 2007

ISSN 1553-3468

(C) 2007 Science Publications

\title{
Agrobacterium-mediated Genetic Transformation in Cucumber (Cucumis sativus L.)
}

\author{
${ }^{1}$ A. Vasudevan, ${ }^{2}$ N. Selvaraj, ${ }^{3}$ A. Ganapathi and ${ }^{1}$ C.W. Choi \\ ${ }^{1}$ Department of Biology and Medicinal Science, Pai Chai University, Daejeon 302735, Republic of Korea \\ ${ }^{2}$ Department of Botany, Periyar E. V.R. College (Autonomous), Tiruchirappalli 620023, T. N., India \\ ${ }^{3}$ Department of Biotechnology, Bharathidasan University, Tiruchirappalli 620024, T. N., India
}

\begin{abstract}
The present study was undertaken to develop efficient transformation protocol for cucumber cv. Poinsett 76 using Agrobacterium strain EHA 105. Five-day-old mature cotyledon explants was used for transformation study. The infected explants were co-cultivated for 2 days in MS medium containing BA $\left(1.0 \mathrm{mg} \mathrm{L}^{-1}\right)$. The selection of transformed shoots was carried out in MS medium fortified with BA $\left(1.0 \mathrm{mg} \mathrm{L}^{-1}\right)$, Cefotaxime $\left(300 \mathrm{mg} \mathrm{L}^{-1}\right)$ and PPT $\left(2.0 \mathrm{mg} \mathrm{L}^{-1}\right)$. The transformed shoots were elongated in MS medium containing BA $\left(1.0 \mathrm{mg} \mathrm{L}^{-1}\right)$, Cefotaxime $\left(300 \mathrm{mg} \mathrm{L}^{-1}\right)$, PPT $(2.0$ $\mathrm{mg} \mathrm{L}^{-1}$ ) along with $\mathrm{GA}_{3}\left(0.5 \mathrm{mg} \mathrm{L}^{-1}\right)$. The rooting of elongated shoots was achieved in MS medium with BA (1.0 mg L $\left.\mathrm{m}^{-1}\right)$, Cefotaxime (300 $\left.\mathrm{mg} \mathrm{L}^{-1}\right)$, PPT $\left(2.0 \mathrm{mg} \mathrm{L}^{-1}\right)$ and IBA $\left(0.6 \mathrm{mg} \mathrm{L}^{-1}\right)$. The transient GUS expression assay and leaf disc assay were carried out in order to find transformed shoots. The molecular confirmation of transformed shoots revealed the foreign gene integration into cucumber genome.
\end{abstract}

Key words: cucumber, Agrobacterium, cotyledon, GUS expression

\section{INTRODUCTION}

Genetic engineering has many potential applications in fields such as medicine, agriculture and industries. In agriculture, the new application of genetic engineering includes the development of transgenic plants. The transgenic plants carry desirable traits like disease resistance, insect resistance and herbicide resistance. Eventually transgenic technology may be used for increasing photosynthetic efficiency, nitrogenfixing ability and production of hybrid crops for food processing and molecular farming ${ }^{[1-4]}$.

In order to establish a successful programme of practical plant genetic engineering, it is important to develop systems for the recovery of whole plants in large members from primary explants. This needs to be done while optimizing the procedure for introducing foreign genes into the species of interest. Tissue culture techniques can be extended to regenerate cucumber plants in large number at a reasonably shorter period. The unique ability of isolated plant cells to regenerate into whole plant ${ }^{[5]}$ (totipotency) means that there is a wide range of potential target cell types for transformation. However, there is no universally applicable method of culture, regeneration and transformation systems for all species, as tissues from different genotypes will differ in their response to culture. A procedure to produce shoots through regeneration from one cultivar may be very different from that of another cultivar within the same species ${ }^{[6]}$. Therefore culture and regeneration protocols must be modified appropriately for cultures of each species $^{[7]}$.

Cucumber has a narrow genetic base and several crossing barriers hamper the introduction of desired traits from the related species ${ }^{[8]}$. The development of gene transfer technology for cucumber can be used to transfer engineered genes for improving its genotype. Among the cucumber cultivars, Poinsett 76 have been widely cultivated in India. The development of reproducible tissue culture and genetic transformation protocols in this cultivar and their applications would improve the cucumber cultivation and benefit cucumber industry in the years to come.

Among the available gene transfer systems, Agrobacterium-mediated gene transfer is considered as more efficient for the stable integration of genes into plant genome. So far, a few reports are available on gene transfer studies of cucumber ${ }^{[9-16]}$. Based on these reports, the present study was focused on Agrobacterium-mediated transformation via direct regeneration using cotyledon explants in an important cultivar, Poinsett 76 with an important Agrobacterium tumefaciens strain EHA $105^{[17] .}$

Corresponding Author: A. Vasudevan, Department of Biology and Medicinal Science, Pai Chai University, Daejeon 302735, Republic of Korea, Tel: +82 425205104 Fax: +82 425205380 


\section{MATERIALS AND METHODS}

Plant material: Seeds of cucumber cultivar Poinsett 76, (Indo-American Hybrid Seeds (India) Pvt Ltd., Bangalore, India) was procured and used for transformation experiments. The seeds were sterilized by washing in Teepol (commercial bleach solution, $0.6 \%$ sodium hypochlorite, Reckitt Benckiser (India) Ltd., Kolkatta, India) for $15 \mathrm{~min}$., rinsed with distilled water three times, followed by soaking in it for $8 \mathrm{hr}$. The soaked seeds were treated with $70 \%$ ethyl alcohol for $30 \mathrm{sec}$, then rinsed with sterile water for three times and surface sterilized in $0.1 \%(\mathrm{w} / \mathrm{v})$ mercuric chloride solution for $3 \mathrm{~min}$. Then the seeds were rinsed with sterile water three times to remove the surface sterilant.

Pre-culture of explants: The sterilized seeds were kept in sterile moist cotton for $24 \mathrm{hr}$. Then their seed coats were separated and aseptically removed without disturbing the cotyledons. The cotyledons were carefully dissected from the embryonic axis. The distal end of the cotyledon explants $(0.5 \mathrm{~cm}$ in length) was cut or injured slightly in such a way that the distal end touched the medium. MS medium ${ }^{[18]}$ containing BA (6benzylamino purine) $\left(1.0 \mathrm{mg} \mathrm{L}^{-1}\right)$ and L-Glutamine (20 $\mathrm{mg} \mathrm{L^{-1 }}$ ) was used for shoot regeneration. The cultures were kept at $25 \pm 2{ }^{\circ} \mathrm{C}$ with a $16 \mathrm{~h}$ photoperiod with the light intensity of $30 \mu \mathrm{mol} \mathrm{m} \mathrm{m}^{-2} \mathrm{~s}^{-1}$ under cool white fluorescent lamps.

Sensitivity of cotyledon explants to PPT: The sensitivity test of PPT was carried out in order to find the inhibitory concentration which arrests cotyledon growth. The sensitivity of cotyledon explants to PPT was determined by culturing the explants in shoot induction medium $\left[\mathrm{MS}+\mathrm{BA}\left(1.0 \mathrm{mg} \mathrm{L}^{-1}\right)+\mathrm{L}-\right.$ Glutamine $\left(20 \mathrm{mg} \mathrm{L}^{-1}\right)$ ] along with PPT (Hoechst, Germany) from 0.5 to $2.0 \mathrm{mg} \mathrm{L} \mathrm{L}^{-1}$. The minimum inhibitory concentration (MIC) of the selection marker was used throughout the selection procedure of transformed shoots from explants. A positive control without selection agent was also maintained.

Agrobacterium strain and plasmid vector: Transformation was performed using Agrobacterium tumefaciens strain EHA 105. This strain harbored the plasmid pGA492GL (kindly provided by Rafael Perl Treves, Bar Ilan University, Israel), carrying $n p t$ II gene regulated by nos promoter and the bar and gus (uid A) genes regulated by CaMV $35 \mathrm{~S}$ promoter (Fig. 1). The gus has an intron in the N-terminal region of the coding

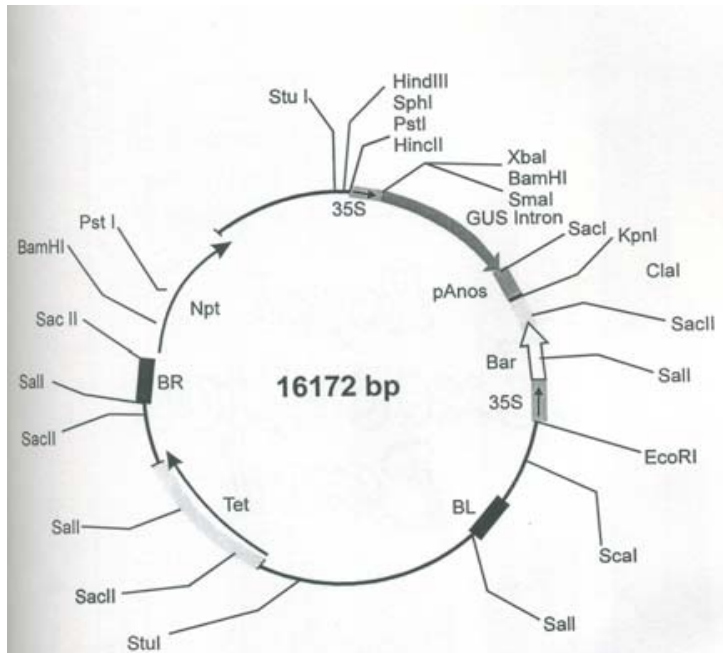

Fig. 1: pME524 showing map of plasmid pGA492GL-Bar $(+)$ carrying GUS, npt II, bar and location of restriction sites

sequence. The bar gene confers resistance to phosphinothricin.

Agrobacterium culture: A single colony of Agrobacterium tumefaciens strain, EHA 105 suspended in $5 \mathrm{ml}$ of Luria-Bertaini (LB) medium containing 50 $\mathrm{mg} \mathrm{\textrm {L } ^ { - 1 }}$ kanamycin (Sigma, USA) and $10 \mathrm{mg} \mathrm{L}^{-1}$ tetracycline (Sigma, USA), was incubated at $28^{\circ} \mathrm{C}$ on a shaker (Orbitek, India) at $200 \mathrm{rpm}$ for $24 \mathrm{hr}$. The suspension of the Agrobacterium strains was diluted with a liquid half strength medium to obtain 1.0 OD $(600 \mathrm{~nm})$ concentration $\left(5 \times 10^{8}\right.$ cells $\left.\mathrm{L}^{-1}\right)$. One hour before the co-cultivation of explants, acetosyringone (10-50 $\mu M)$ was added.

Agrobacterium infection and co-cultivation: The proximal end of the cotyledon was gently pricked for ten times to make wounds using sterile needle (Dispovan India Ltd., $0.63 \times 25 \mathrm{~mm}$ ). Then the cotyledon explants were immersed in the bacterial culture for $10 \mathrm{~min}$. After that the explants were removed, blotted dry using sterile Whatman no.1 filter paper and inoculated (one explant/culture tube) on MS medium containing BA $\left(1.0 \mathrm{mg} \mathrm{L}^{-1}\right)$ and $\mathrm{ABA}(0.5 \mathrm{mg}$ $\left.\mathrm{L}^{-1}\right)$. The co-cultivation was performed for $0,1,2,3,4$ and 5 days under a $16 \mathrm{~h}$ photoperiod with a light intensity of $30 \mu \mathrm{mol} \mathrm{m}{ }^{-2} \mathrm{~s}^{-1}$ and kept at $25 \pm 2{ }^{\circ} \mathrm{C}$.

Selection of transformants: After co-cultivation, the explants were washed three times with sterile distilled water containing filter sterilized cefotaxime (300 mg L $\mathrm{L}^{-1}$ ) (Hoechst Marion Roussel Ltd., Mumbai, 
India), blotted dry and were subjected to selection. The cultures were maintained under $16 \mathrm{~h}$ photoperiod (30

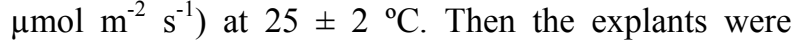
transferred to MS medium supplemented with BA (1.0 $\left.\mathrm{mg} \mathrm{L}^{-1}\right)$, cefotaxime $\left(300 \mathrm{mg} \mathrm{L}^{-1}\right)$ along with PPT $(2.0$ $\mathrm{mg} \mathrm{L}^{-1}$ ) for shoot bud induction. After 2-3 weeks, the explants with emerging shoots were transferred to MS medium containing BA $\left(1.0 \mathrm{mg} \mathrm{L}^{-1}\right)$, cefotaxime (300 $\left.\mathrm{mg} \mathrm{L}^{-1}\right)$ and PPT (2.0 $\left.\mathrm{mg} \mathrm{L}^{-1}\right)$ for shoot proliferation. Two subcultures were done on the same medium at 25$\mathrm{d}$ interval. The medium of the same composition was changed once in 10 days. The regenerated shoots were excised from the explants and transferred to MS medium supplemented with $\mathrm{BA}\left(1.0 \mathrm{mg} \mathrm{L}^{-1}\right), \mathrm{GA}_{3}(0.5$ $\left.\mathrm{mg} \mathrm{L}^{-1}\right)$, cefotaxime (300 $\left.\mathrm{mg} \mathrm{L}^{-1}\right)$ and PPT $\left(2.0 \mathrm{mg} \mathrm{L}^{-1}\right)$ for shoot elongation. The elongated shoots were then transferred to MS medium fortified with IBA $(0.6 \mathrm{mg}$ $\left.\mathrm{L}^{-1}\right)$, cefotaxime $\left(300 \mathrm{mg} \mathrm{L}^{-1}\right)$ and PPT $\left(2.0 \mathrm{mg} \mathrm{L}^{-1}\right)$ for rooting. The rooted plants were transferred to pots containing sterilized sand, soil and vermiculite (2:1:1 $\mathrm{v} / \mathrm{v} / \mathrm{v})$ mixture and were acclimatized in green-house for 30 days.

Leaf disc assay: Four week old putative transformed shoots derived from cotyledon explants were aseptically divided into small pieces using sterile blade. The leaves were transferred to petriplates containing MS medium with BA $\left(1.0 \mathrm{mg} \mathrm{L}^{-1}\right)$ and PPT $\left(2.0 \mathrm{mg} \mathrm{L}^{-1}\right)$ in order to find out the lethal effect of transformed and nontransformed shoots. The petriplates containing leaves from transformed and non-transformed shoots were incubated for 1 week under a $16 \mathrm{~h}$ photoperiod with a light intensity of $30 \mu \mathrm{mol} \mathrm{m} \mathrm{s}^{-2}$ and kept at $25 \pm 2{ }^{\circ} \mathrm{C}$.

GUS assay: Explants were assayed for the expression of gus A int gene following the histochemical procedure $^{[19]}$. Cotyledon explants $8 \mathrm{hr}$ after cocultivation and 3-week old young leaves from transformants were washed in distilled water three times and followed by incubation for $10 \mathrm{~min}$ in phosphate buffer $\left(0.5 \mathrm{mM} \mathrm{NaH} \mathrm{NOO}_{4}\right.$ and $0.5 \mathrm{~m} M$ $\mathrm{Na}_{2} \mathrm{HPO}_{4}$ ), pH 7.0 containing $0.5 \mathrm{mM}$ potassium ferri and ferro cyanide and $10 \mathrm{~m} M \mathrm{Na}_{2}$ EDTA. The buffer was removed and fresh phosphate buffer containing $1 \%$ $(\mathrm{v} / \mathrm{v})$ Triton X-100 was added to the leaf tissues and incubated for $1 \mathrm{~h}$ at $37{ }^{\circ} \mathrm{C}$ after draining the solution, again fresh phosphate buffer containing $1.0 \mathrm{~m} M \mathrm{X}$-gluc (5-bromo-4-chloro-3-indolyl $\beta$-D glucuronide) and 20\% of $95 \%$ methanol was added. The reaction was placed under a mild vacuum for 5 minutes and incubated overnight at $37^{\circ} \mathrm{C}$ and then the tissues were examined visually. Following the incubation the chlorophyll was removed and fixed in 95\% (v/v) ethanol:1\% (v/v) glacial acetic acid.

Statistical analysis: Each treatment consisted of a total of 110 explants and each experiment was repeated for three times. A completely randomized design was used in all experiments and analysis of variance and mean separations were carried out using Duncan's Multiple Range Test (DMRT). Significance was determined at $\mathrm{p}<0.05$ level ${ }^{[20]}$.

The percentage of GUS expression was calculated by the number of explants showing GUS positive divided by the number of explants subjected to cocultivation and multiplied by $100^{[21]}$.

\section{Molecular confirmation of transformants}

* Isolation of Genomic DNA: Genomic DNA was isolated from young leaves of control and transformed plants using previous method ${ }^{[22]}$.

* PCR confirmation: For PCR analysis, DNA samples from putative transformants were amplified by bar specific primers. The bar gene fragment $(0.46 \mathrm{~kb})$ was amplified by using the forward primer - 5'-ATC GTC AAC TAC ATC GAG AC - 3' and reverse primer 5'-CCA GCT GCC AGA AAC CCA CGT C-3.'

All PCR reactions were performed using a Peltier effect thermal cycler (MJ Research Co., USA). Samples containing $50 \mathrm{ng}$ genomic DNA were first heated at 94 ${ }^{\circ} \mathrm{C}$ for $5 \mathrm{~min}$ followed by 30 cycles at $94{ }^{\circ} \mathrm{C}$ for 30 s, 55 ${ }^{\circ} \mathrm{C}$ and $72{ }^{\circ} \mathrm{C}$ for $30 \mathrm{~s}$ followed by $7 \mathrm{~min}$ final extension at $72^{\circ} \mathrm{C}$. Fifty ng of plasmid DNA was used as positive control. The PCR reactions contained $10 \mathrm{p} M$ of each primer, $10 \mathrm{~m} M$ dNTPs mix, $15 \mathrm{mM} \mathrm{MgCl}_{2}, 50 \mathrm{mM}$ $\mathrm{KCl}, 10 \mathrm{~m} M$ Tris $\mathrm{HCl}(\mathrm{pH} 9.0), 0.1 \%$ (v/v) Triton X$100,2 \mathrm{U}$ of Taq DNA polymerase and $50 \mathrm{ng}$ of template DNA in $2 \mathrm{X}$ reaction buffer. The amplified DNA were analysed by using $1.5 \%$ agarose gel electrophoresis.

* Southern hybridization: The blotting procedures were followed by standardized method ${ }^{[23]}$. The bar gene probe was labeled by non radioactive labelling kit (ECL random labelling and detection system) (Amersham Biosciences, UK). The blot was prehybridized at $60{ }^{\circ} \mathrm{C}$ for one hour in hybridization buffer (5X SSC, blocking agent $(0.5$ $\%(\mathrm{w} / \mathrm{v})$, SDS $(0.1 \%)$ and dextran sulphate $(5 \%)$. The denatured labeled probe was added to the hybridization oven (Amersham Biosciences, UK). Post hybridization washes were performed in high stringency conditions. The blot was washed in an excess of $1 \mathrm{X} \mathrm{SSC}, 0.1 \%$ for $15 \mathrm{~min}$, then in SSC $(0.5 \%)$ and SSC $(0.1 \%$ with SDS $(0.1 \%)$. 
After hybridization, the blot was rinsed briefly in antibody wash buffer (Tris- $\mathrm{HCl} 100 \mathrm{mM}, \mathrm{NaCl} 150$ $\mathrm{m} M$ and $\mathrm{pH}$ 7.0). The blot was blocked with blocking agent $(0.5 \%)$ (supplied by the manufacturer of ECL kit) at room temperature for one hour with continuous agitation. After a brief rinse in antibody wash buffer, the blot was incubated with antibody diluted 1000 fold in BSA $(0.5 \%)$ (fraction V) (w/v) in antibody wash buffer and incubated for one hour at room temperature with continuous agitation. Membranes were washed with antibody wash buffer with Tween $20(0.1 \%)(\mathrm{v} / \mathrm{v})$ for 210 min followed by washing in 2 X 5 min at room temperature with continuous agitation.

After removal of excess antibody, the blot was wetted with the detection solutions $1 \& 2$ (Supplied by ECL manufactures). Excess of detection solution was drained from the membrane and the blot was covered by saran wrap. The covered blot was immediately placed in X-ray cassettes with X-ray film. After one hour the X-ray film was developed and the signal was detected in X-ray film.

\section{RESULTS AND DISCUSSION}

Plant material: Cotyledon explants (proximal half; 0.5 $\mathrm{cm}$ in length), derived from mature seeds of cucumber cultivar Poinsett 76 was used as target tissue for Agrobacterium-mediated gene transfer through direct regeneration. Mature cotyledon explants were used in the transformation study. In vitro regeneration of plants from cotyledons of mature seeds and young seedlings has received considerable attention in the recent years and this is most likely because of the easy accessibility, quick response and high ability for shoot organogenesis ${ }^{[24]}$. The use of mature cotyledon explant in the present study was justified with earlier transformation experiments in melon ${ }^{[25]}$ and in cucumber cultivars $^{[15,16,26]}$.

Pre-culture of explants: In the present study, a 5-dayold pre-cultivation period was found suitable for cotyledon explants of Poinsett 76 in shoot bud induction medium $\left[\mathrm{MS}+\mathrm{BA}\left(1.0 \mathrm{mg} \mathrm{L}^{-1}\right)+\mathrm{L}-\right.$ Glutamine $\left.\left(20 \mathrm{mg} \mathrm{L}^{-1}\right)\right]$ to induce shoot bud at the proximal region and more GUS expression (Fig. 2). If explants were co-cultivated immediately without preculture, they were not able to withstand the infection and eventually died (data not shown). Similarly, more escapes were observed from cotyledon explants precultured beyond five days (data not shown). Pre-culture of explants is a critical factor to achieve high frequency of transformation. It makes the explant tissue competent

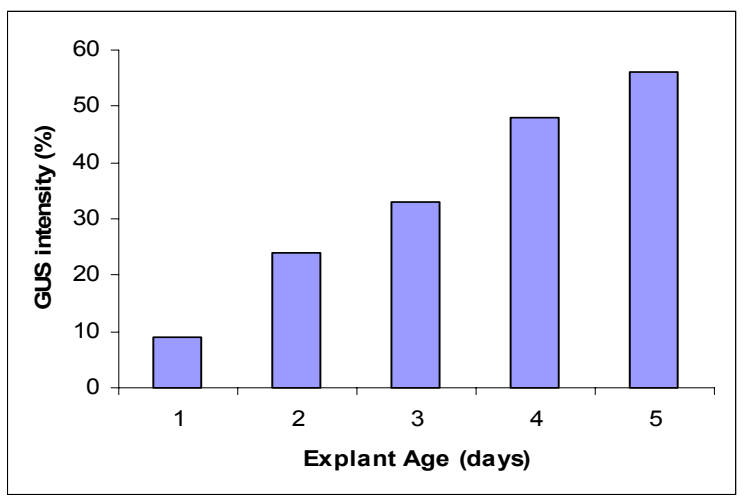

Fig. 2: Effect of age of the cotyledon explants of GUS expression in cucumber cultivars co-cultivated with EHA 105

enough to withstand the bacterial infection and the related stress that followed it. Pre-culturing of explants prior to inoculation and co-cultivation with Agrobacterium has been shown to improve genetic transformation frequencies in some woody fruit plants such as plum ${ }^{[27]}$ and almond ${ }^{[28]}$. In this study, 5-day-old pre-cultured cotyledons were used for transformation. Five-day-old cotyledon explants did produce higher number of transformed shoots than the explants of other age. Beyond $5^{\text {th }}$ day, cotyledon explants produced shoots but most of them were escapes due to preemergence of shoot primordia from the explants before agro infection. Our study was in conformity with earlier reports on cucumber ${ }^{[15,26]}$. For cucumber transformation studies, three to seven-day-old in vitro grown seedlings were used as donors of cotyledon explants ${ }^{[9,10,15,16,27,29]}$. On the other hand, 1-day-old cultured cotyledon explants of cucumber used for transformation procedure $^{[14]}$.

Sensitivity of cotyledon explants to PPT: In order to find out the appropriate concentration of selection agent, to effectively screen transformed shoots in the cultivar Poinsett 76, we employed different concentrations of PPT during shoot bud production. Control shoots developed normally in the selective agent free medium. Maximum number of shoot buds was obtained at $0.5 \mathrm{mg} \mathrm{L}^{-1} \mathrm{PPT}$. At $1.0 \mathrm{mg} \mathrm{L}^{-1} \mathrm{PPT}$ fifty percentage of explants showed necrosis. Further increase in the level of PPT led to a corresponding decrease in the shoot bud production. PPT at $2.0 \mathrm{mg} \mathrm{L}^{-1}$ caused almost total inhibition of bud production and regeneration from cotyledon explants (Fig. 3A). Therefore, this concentration was used for the selection of shoots with minimal escapes. In the earlier studies, PPT selection of transformed shoots of cucumber has been adopted with successful results ${ }^{[15]}$. 
Am. J. Biochem. \& Biotech., 3 (1): 24-32, 2007

Table 1: Transformation efficiency of Agrobacterium strain EHA 105 with $20 \mu M$ acetosyringone for cv. Poinsett 76 in PPT (2.0 mg $\left.1^{-1}\right)$

\begin{tabular}{|c|c|c|c|c|c|c|}
\hline \multirow{2}{*}{ Agrobacterium strain } & \multirow{2}{*}{$\begin{array}{l}\text { Exp. } \\
\text { No. }\end{array}$} & \multirow{2}{*}{$\begin{array}{l}\text { No of } \\
\text { cotyledon } \\
\text { explants } \\
\text { infected } \\
\end{array}$} & \multirow{2}{*}{$\begin{array}{l}\text { No of GUS positive } \\
\text { shoots } \\
\text { (without } \\
\text { acetosyringone) }\end{array}$} & \multirow{2}{*}{$\begin{array}{l}\text { No of GUS positive } \\
\text { shoots } \\
\text { (with acetosyringone) }\end{array}$} & \multicolumn{2}{|c|}{ Efficiency of transformation (\%) } \\
\hline & & & & & $\begin{array}{l}\text { Without } \\
\text { acetosyringone }\end{array}$ & $\begin{array}{l}\text { With } \\
\text { acetosyringone }\end{array}$ \\
\hline EHA105 & 1 & 110 & 1 & 8 & 0.9 & 7.2 \\
\hline & 2 & 110 & 1 & 7 & 0.9 & 6.0 \\
\hline & 3 & 110 & 3 & 3 & 2.7 & 6.4 \\
\hline & 4 & 110 & 2 & 5 & 1.8 & 6.8 \\
\hline & 5 & 110 & 1 & 15 & 0.9 & 6.8 \\
\hline & Total & 550 & 8 & 36 & 1.5 & 6.6 \\
\hline
\end{tabular}
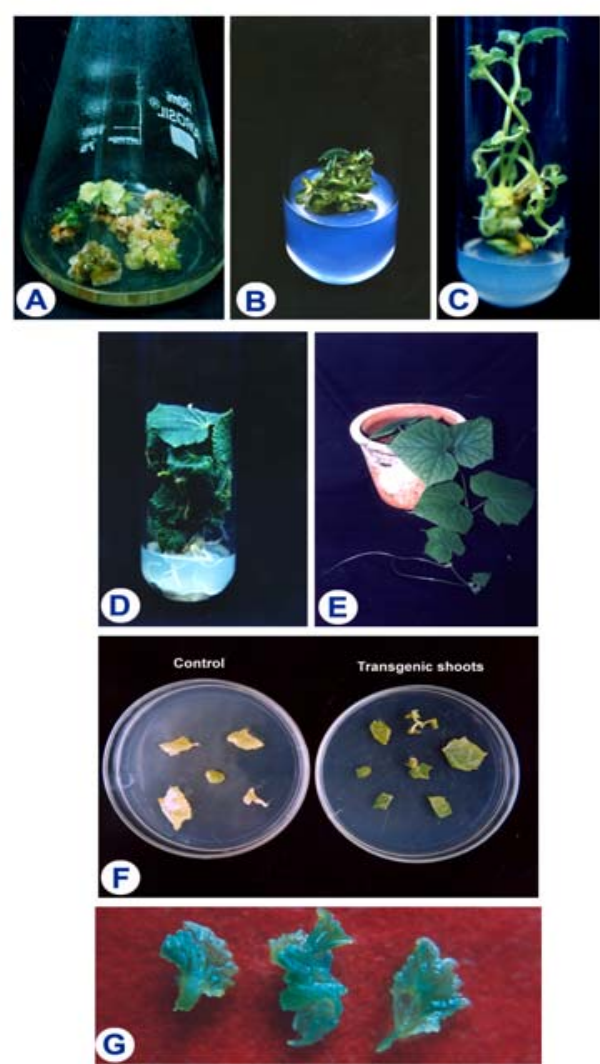

Fig. 3: Transformation of Cucumis sativus L. cotyledon explants by Agrobacterium tumefaciens strain EHA 105

A. Sensitivity of cotyledon explants $\left[\mathrm{MS}+\mathrm{BA}\left(1.0 \mathrm{mg} \mathrm{L}^{-1}\right)_{-}\right.$ L-Glutamine (20 $\left.\mathrm{mg} \mathrm{L}^{-1}\right)+$ PPT $\left.\left(2.0 \mathrm{mg} \mathrm{L}^{-1}\right)\right]$

B. Proliferation of transformed shoots $[\mathrm{MS}+\mathrm{BA}(1.0 \mathrm{mg}$ $\left.\mathrm{L}^{-1}\right)+$ Cefotaxime $\left.\left.9300 \mathrm{mg} \mathrm{L}^{-1}\right)+\operatorname{PPT}\left(2.0 \mathrm{mg} \mathrm{L}^{-1}\right)\right]$

C. $\quad$ Elongation of transformed shoots $\left[\mathrm{MS}+\mathrm{BA}\left(1.0 \mathrm{mg} \mathrm{\textrm {L } ^ { - 1 }}\right)\right.$ $+\mathrm{GA} 3\left(0.5 \mathrm{mg} \mathrm{L}^{-1}\right)+$ Cefotaxime $\left(300 \mathrm{mg} \mathrm{L}^{-1}\right)+\mathrm{PPT}$ $\left(2.0 \mathrm{mg} \mathrm{L}^{-1}\right)$ ]

D. Rooting of elongated transformed shoots [MS + BA (1.0 $\left.\mathrm{mg} \mathrm{L} \mathrm{L}^{-1}\right)+\operatorname{IBA}\left(0.6 \mathrm{mg} \mathrm{L}^{-1}\right)+$ Cefotaxime $\left(300 \mathrm{mg} \mathrm{L}^{-1}\right)+$ PPT (2.0 $\left.\left.\mathrm{mg} \mathrm{L}^{-1}\right)\right]$

E. Hardening of transformed plant in pot (Sand:Soil:vermiculite 1:1:1 v/v/v)

F. Leaf disc assay of transformed shoots [(MS + BA (1.0 mg $\left.\mathrm{L}^{-1}\right)+$ PPT $\left.\left(2.0 \mathrm{mg} \mathrm{L}^{-1}\right)\right]$

G. GUS expression in 2-week-old transformed shoots
Agrobacterium strain and plasmid vector: Agrobacterium strain EHA 105 containing the plasmid pGA492GL-Bar $(+)$ was used in this study. The total number of explants infected was 550 for each strain and the experiment was repeated 3 times. EHA 105 showed greater infectivity in transformation. The transformation frequency was $6.6 \%$ for EHA 105 in Poinsett 76 (Table 1). A large number of Agrobacterium tumefaciens strains were isolated and several of them have been modified for use in transformation studies. Virulence of Agrobacterium tumefaciens strains varies widely among plant hosts ${ }^{[30-32]}$. In the present study, EHA 105 strain was employed for transformation into cucumber. This strain have already been deployed in earlier study in cucumber ${ }^{[16]}$. This is in agreement with previous study ${ }^{[16]}$ where the transformation efficiency was 6.4 in EHA 105. Agrobacterium strain EHA 105 was more effective because its derived from super virulent wild type strain $\mathrm{A} 281^{[18]}$.

\section{Agrobacterium infection and co-cultivation: Transformation experiments were performed to} optimize the effective Agrobacterium density, acetosyringone concentration and co-cultivation period. In the present study, an inoculum density of $1.0 \mathrm{OD}$ $(600 \mathrm{~nm})$ was optimal for co-cultivation of cotyledon explants (data not shown). Co-cultivation period was assessed for each day from 0 day to $5^{\text {th }}$ day. A 2 -day cocultivation was found optimal for Poinsett 76 in MS medium containing BA $\left(1.0 \mathrm{mg} \mathrm{L}^{-1}\right)$ and $\mathrm{ABA}(0.5 \mathrm{mg}$ $\mathrm{L}^{-1}$ ) which led to the production of significantly higher rate of GUS expression as compared to other days of co-cultivation (Table 2). In this cultivar the optical density greater than $1.0 \mathrm{OD}$ and co-cultivation beyond 3 days led to bacterial over growth and leaching of bacteria from explants (data not shown).

Among the different concentrations of acetosyringone tested, $20 \mu M$ was optimum for Poinsett 76 , beyond which shoot recovery was not possible due to bacterial overgrowth from explants (Table 1). The transformation efficiency in the cultivar Poinsett 76 was 
Am. J. Biochem. \& Biotech., 3 (1): 24-32, 2007

Table 2: Effect of co-cultivation period on GUS expression in cotyledon explants derived from 1-5 - day - old seedlings of cucumber cultivars co-cultivated with EHA 105

\begin{tabular}{llllll}
\hline Cultivar & \multicolumn{4}{l}{ Percentage of GUS expression } \\
& Days of co-cultivation & & \\
\hline Poinsett 76 & 1 & 2 & 3 & 4 & 5 \\
& $20 \mathrm{c}, 16 \mathrm{bc}$ & $31 \mathrm{c}, 27 \mathrm{bc}$ & $45 \mathrm{c}, 39 \mathrm{bc}$ & $64 \mathrm{bc}, 57 \mathrm{bc}$ & $78 \mathrm{bc}, 61 \mathrm{c}$ \\
\hline
\end{tabular}

Each value represents the treatment means of 110 explants and repeated three times.

Values with the same letter within columns are not significantly different according to Duncan's Multiple Range Test (DMRT) at 5\% level.

$6.6 \%$ at $20 \mu M$ acetosyringone The inoculum density at 1.0 OD was used in the present experiment. Our results were in conformity with previous studies ${ }^{[9,10,16,26]}$ in cucumber that 1.0 OD was essential for effective transformation. Different co-cultivation period was found optimal for the effective infection and regeneration of transgenic shoots ${ }^{[10,12,14,26]}$. The cocultivation period beyond 4 days the calluses with free of Agrobacterium contamination were more difficult to obtain for cucumber ${ }^{[13]}$. In the present study, a 2-dayold co-cultivation for Poinsett 76 was found suitable for effective transformation. The use of acetosyringone (20-50 $\mu M)$ enhanced the infection frequency during co-cultivation. Agrobacterium is presumably attracted to a wounded plant in response to signal molecules released by the plant cells to which it then becomes attracted ${ }^{[33,34]}$. The results of the present study are in agreement with previous observations ${ }^{[12,13,27,35]}$.

Selection of transformants: Inclusion of selection agent in the regeneration and rooting media was responsible for the production of putative transformed shoots that stably expressed transgenes. In the present study, PPT was employed for selection of transformants. The explants inoculated in MS medium containing selection agent PPT $\left(2.0 \mathrm{mg} \mathrm{L}^{-1}\right)$ produced transformed shoots with a transformation frequency of $6.3 \%$ for cv. Poinsett 76 (Fig. 3B). Among the 110 explants infected with Agrobacterium strain EHA 105, 7 explants produced transgenic shoots in Poinsett 76. Other explants did not respond to shoot regeneration and ultimately died. After 3 weeks of culture the selected shoots were elongated, rooted and hardened (Figs. 2.3C, D \& E). Bar gene in conjunction with phosphinothricin has been shown to be an effective selectable marker in obtaining transgenic plants in cucumber $^{[15]}$, Arabidopsis $^{[36]}$, Carrot $^{[37]}$, Lotus $^{[38]}$, Medicago $^{[39]}$, Pea $^{[40]}$, Soybean ${ }^{[41]}$ and Sugarcane ${ }^{[42]}$.

Leaf disc assay: The leaf disc $(5 \mathrm{~cm}$ long) taken from 2-month-old putative transformed shoots in the medium containing BA $\left(1.0 \mathrm{mg} \mathrm{L}^{-1}\right)$ and PPT $\left(2.0 \mathrm{mg} \mathrm{L}^{-1}\right)$ survived without any necrotic symptoms, while nontransformed leaf discs showed necrotic symptoms (Fig. $2.3 \mathrm{~F})$. The percentage of survival of transgenic shoots was $90 \%$, while non-transformed shoots showed $100 \%$ necrosis within a week in the same medium (data not shown). Chimeras were not observed in the transgenic shoots. Leaf disc assay is one of the preliminary tests to identify and compare the transgenic shoots from nontransgenic shoots. Because of high toxicity of PPT, the non-transformed shoots (without bar gene in its genome) were not able to withstand. Phosphinothricin is an analogue of glutamic acid and two L-alanine residues. It is a powerful inhibitor of glutamine synthetase $^{[43]}$. It is believed that inhibition of glutamine synthetase leads to ammonia accumulation resulting in symptoms of chlorophyll bleaching in non-transformed shoots while transformed shoots remained alive without necrotic symptoms or bleaching. The advantage of using PPT for the screening procedure is that it has a localized effect, i.e only those plant cells that uses the active bar gene have the ability to detoxify the herbicide. Leaf disc assay and colour viability test for the plants transformed with Agrobacterium strain EHA 105 under the selection of PPT revealed more positive results compared to the wild type control plants ${ }^{[44]}$. In tobacco primary mode of action for glyphosate and PPT herbicides on non-transformed shoots leads to lethal effect ${ }^{[45]}$. Transgenic lines arising after the herbicide selection phase were subjected to leaf disc assay showed non lethal effect. Hence in the present treatment, leaves of non-infected explants showed chlorophyll bleaching whereas those of transformed plants remained alive without chlorophyll bleaching.

GUS assay: The present study was investigated for the GUS expression in cucumber cultivar Poinsett 76. The strong GUS expression was observed in 3-week-old young leaves (Fig. 3G). Our result was collaborative with previous study ${ }^{[16]}$.

\section{Molecular confirmation of transformants}

* PCR confirmation: Molecular analysis through PCR amplification confirmed the presence of bar gene in the putative transformants, co-cultivated either with EHA 105 strain. The DNA isolated from putative transformed shoots, control plants and plasmid pGA492GL were used as template DNA. The suitable primers for bar gene was used for PCR amplification. The presence of amplified band at $0.46 \mathrm{~kb}$ in transformed shoots confirmed the presence of bar gene (Fig. 4; lanes 3-8). 


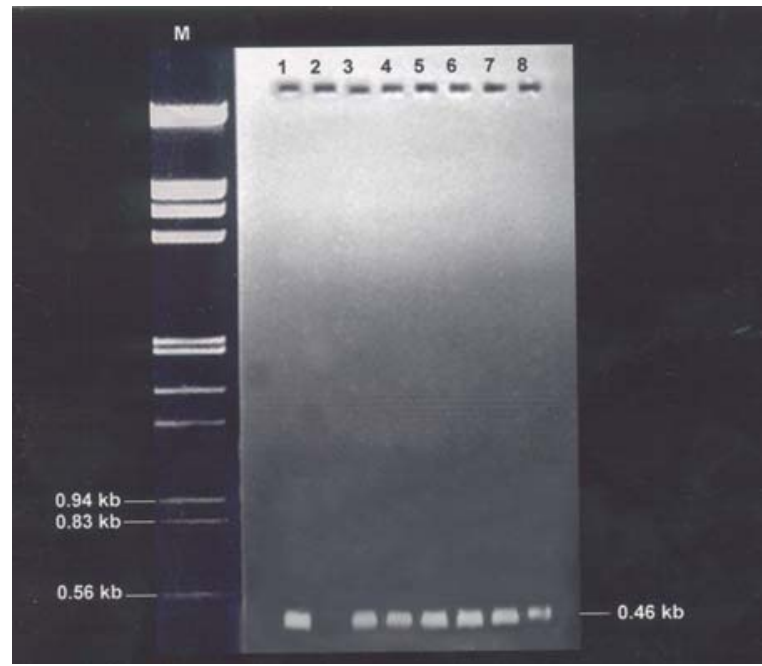

Fig. 4: PCR confirmation of transformed shoots. Arrows indicates the amplification of bar gene $(0.46 \mathrm{~kb})$

M- Lambda Hind III Marker $(1.0 \mathrm{~kb})$

Lane 1: $\quad$ Plasmid DNA (pGA492GL) (positive control)

Lane 2: DNA samples from non-transformed shoots (negative control)

Lane 3-8: DNA samples from transformed shoots

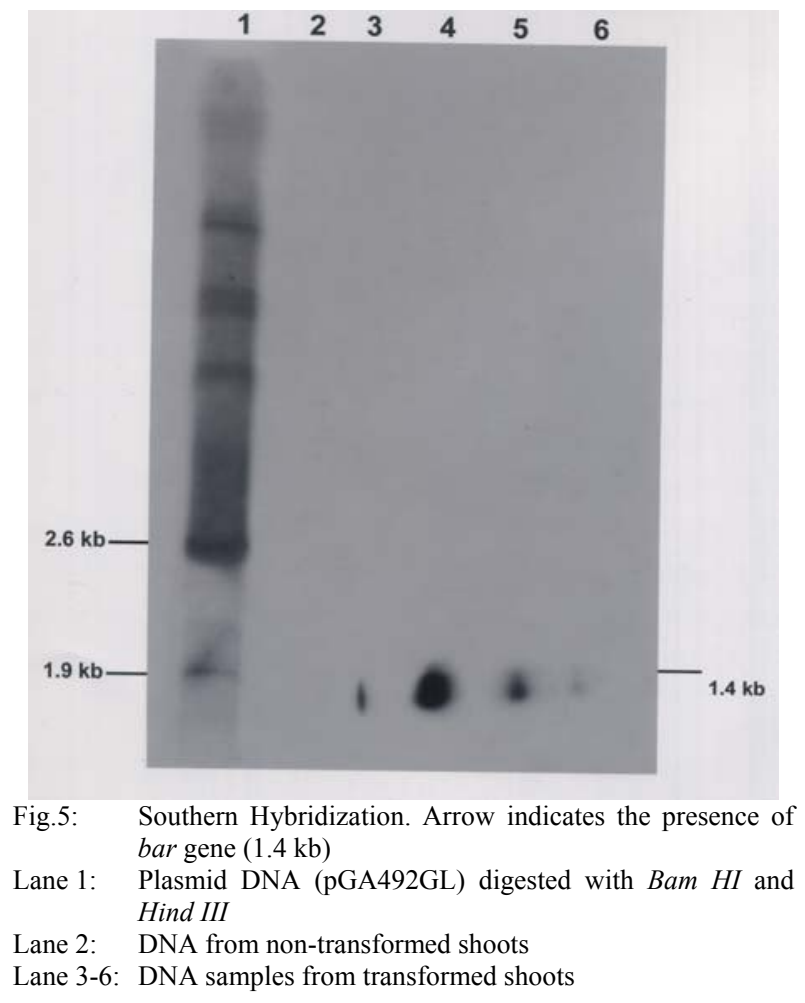

The amplification was not seen in non-transformed control shoots (Fig. 4; lane 2). The amplification of the same $(0.46 \mathrm{~kb})$ was observed from the lanes loaded with plasmid DNA pGA492GL (Fig. 4; lane 1).

* Southern hybridization: Southern hybridization was carried out on genomic DNA from GUS positive, shoots developed on cotyledon explants. The bar gene was detected as a Bam HI and Hind III digested bar fragment of expected size $(1.4 \mathrm{~kb})$ in the shoots transformed with EHA 105. As the bar fragment probe hybridized to digested DNA from transgenic shoots (Fig. 5; lanes 3-6) but not hybridized to non-transformed control leaves (Fig. 5; lane 2). Fig. 5; lane 1 indicated plasmid DNA (pGA492GL) carried bar fragment which cleaved under digestion with restriction enzymes (Bam HI and Hind III).

\section{CONCLUSION}

The success in production of stably transformed shoots from cotyledon explants reported here appears to be due to at least three key factors; first was the choice of the explant (cotyledon), second was the use of efficient reporter gene, the GUS and the third was the use of PPT as the selective agent. This method offers several advantages: i) the cotyledons are available throughout the year from mature dry seeds; the protocol is rapid and ii) as the regeneration occurs through direct organogenesis, genetic variation/abnormalities often associated with regeneration of plants from callus are expectedly avoided.

In conclusion, a reliable transformation protocol was standardized using Agrobacterium strain EHA 105 with reference to cucumber cultivar Poinsett 76. This protocol may be adopted for transferring any character genes of agronomic interest.

\section{REFERENCES}

1. Kung, S.D., 1993. Introduction: From Hybrid Plants to Transgenic Plants. In: Transgenic Plants, Engineering and Utilization. (Eds.) Kung, S.D. and R. Wu, Vol. 1. Academic Press, San Diego, USA, pp: $1-12$.

2. Suzuki, S., N. Murai, N. James, R. Burnell and R. Arai, 2000. Changes in photosynthetic carbon flow in transgenic rice plants that express C4-Type Phosphoenolpyruvate Carboxykinase from Urochloa panicoides. Plant Physiol., 124: 163-172.

3. Daniell, H., 2001. Medical molecular farming: Production of antibodies, biopharmaceuticals and edible vaccines in plants. Trends in Plant Sci., 6: 219- 226. 
4. Aharon, R., Y. Shahak, S. Wininger, R. Bendov, Y. Kapulnik and G. Galili, 2003. Over expression of a plasma membrane aquaporin in transgenic tobacco improves plant vigor under favorable growth conditions but not under drought or salt stress. Plant Cell, 15: 439-447.

5. Gamborg, O.L., P. Davis and R.W. Stahelut, 1968. Somatic embryogenesis in cell suspension cultures of glycine species. Plant Cell Rep., 2: 209-212.

6. Oridate, T., H. Atsumi, S. Ito and H. Araki, 1992. Genetic difference in somatic embryogenesis from seed in melon (Cucumis melo L.). Plant Cell Tiss. Org. Cult., 29: 27-30.

7. Walden, R. and R. Wingender, 1995. GeneTransfer and Plant- An easy-going general review. Regeneration Techniques. Trends. Biotech., 13: 324-331.

8. Den Nijs, A.P.M. and J.B.M. Custers, 1990. Introduction resistance into cucumbers by interspecific hybridization. Crop Improvement and Protection, p: 382- 396.

9. Chee, P.P., 1990b. Transformation of Cucumis sativus tissue by Agrobacterium tumefaciens and the regeneration of transformed plants. Plant Cell Rep., 9: 245-248.

10. Chee, P.P. and J.L. Slightom, 1991. Transfer and expression of Cucumber Mosaic Virus Coat protein gene in the genome of Cucumis sativus. J. Am. Soc. Hortic. Sci., 116: 1098-1102.

11. Sarmento, G.G., F.A. Alpert, S. Tang and Z.K. Punza, 1992. Factors influencing Agrobacterium tumefaciens mediated transformation and expression of kanamycin resistance in pickling cucumber. Plant Cell Tis. Org. Cult., 31: 185-193.

12. Nishibayashi, S., H. Kaneko and T. Hayakawa, 1996. Transformation of cucumber (Cucumis sativus L.) plants using Agrobacterium tumefaciens and regeneration from hypocotyls explants. Plant Cell Rep., 15: 809-814.

13. Raharjo, S.H.T., M.O. Hernandez, Y.Y. Zhang and Z.K. Punja, 1996. Transformation of pickling cucumber with chitinase - encoding genes using Agrobacterium tumefaciens. Plant Cell Rep., 15: 591-596.

14. Tabei, Y., S. Kitade, Y. Nishibayashi, N. Kikuchi, T. Kayano, T. Hibi and K. Akutsu, 1998. Transgenic cucumber plants harbouring a rice chitinase gene exhibit enhanced resistance to grey mold (Botrytis cinerea). Plant Cell Rep., 17: 159164.
15. Ganapathi, A. and R. Perl-Treves, 2000. Agrobacterium-mediated transformation in Cucumis sativus L. via direct organogenesis. Acta Hortic., 510: 405-407.

16. Soniya, E.V. and M.R. Das, 2002. In vitro organogenesis and genetic transformation in popular Cucumis sativus L. through Agrobacterium tumefaciens. Ind. J. Exp. Biol., 40: 329-333.

17. Hood, E.E., G.L. Helmer, R.T. Fraley and M.D. Chilton, 1986. The hypervirulence of Agrobacterium tumefaciens A281 is encoded in a region of pTiBo542 outside the T-DNA. J. Bacteriol., 169: 1291-1301.

18. Murashige, T. and F. Skoog, 1962. A revised medium for rapid growth and bioassays with tobacco tissue culture. Plant Physiol., 15: 473-497.

19. Jefferson, R.A., T.A. Kavanagh and M.W. Bevan, 1987. GUS fusion: $\beta$-glucuronidase as a sensitive and versatile gene fusion marker in higher plants. EMBO J., 6: 3901-3907.

20. Gomez, K.A. and K.A. Gomez, 1976. Statistical procedures for agricultural research with emphasis of rice. Rice. Res. Inst., Los Banos, Philliphines.

21. Cao, X., Q. Liu, L.J. Rowland and F.A. Hammerschlag, 1998. GUS expression in blueberry (Vaccium spp.): factors influencing Agrobacterium-mediated gene transfer efficiency. Plant Cell Rep., 18: 266-270.

22. Bernatsky, R. and S.D. Tanksley, 1986. Toward a saturated linkage map in tomato based on isozymes and random cDNA sequences. Genetics, 112: 887898.

23. Southern, EM., 1975. Detection of specific sequences among DNA fragments separated by gel electrophoresis. J. Mol. Biol., 98: 503-517.

24. Tabei, Y., T. Kanno and T. Nishio, 1991. Regulation of organogenesis and somatic embryogenesis by auxin in melon, Cucumis melo L. Plant Cell Rep., 10: 225- 229.

25. Gaba, V., E. Feldmesser, A. Gal-On, H. Kles and Y. Antignus, 1995. Genetic Transformation of a Recalcitrant Melon (Cucumis melo L.) Variety. In: Cucurbitaceae' 94. (Eds.), Lester, G. and J. Dunlop, Gateway printing, USA, pp: 188-190.

26. Selvaraj, N., 2002. In Vitro culture and Agrobacterium-mediated genetic transformation in cucumber (Cucumis sativus L.). Ph.D. Thesis, Bharathidasan University, Tiruchirappalli, Tamilnadu, India.

27. Mante, S., P.H. Morgens, R. Scorza, J.M. Cordts and A.M. Callahan, 1991. Agrobacterium-mediated transformation of plum (Prunus domestica L.) hypocotyl slices and regeneration of transgenic plants. Bio Technol., 9: 853-857. 
28. Ainsley, P.J., P.G. Collins and M. Sedgely, 2001. Factors affecting Agrobacterium-mediated gene transfer and the selection of transgenic calli in paper shell almond (Prunus dulcis Mill.). J. Hort. Sci. Biotech., 76: 522-528.

29. Sapountzakis, G. and A.S. Tsaftaris, 1996. Transfer and expression of the firefly Luciferase gene in cucumber. Cucurbits Genet. Coop. Rep., 19: 38-41.

30. Hobbs, S.L.A., J.A. Jackson and J.D. Mahon, 1989. Specificity of strain and genotype in the susceptibility of pea to Agrobacterium tumefaciens. Plant Cell Rep., 8: 55-58.

31. Bush, A.L. and S.G. Pueppke, 1991. Cultivar-strain specificity between Chrysanthemum morifolium and Agrobacterium tumefaciens. Physiol Mol Plant Pathol., 39: 309-323.

32. Davis, M.E., A.R. Miller and R.D. Lineberger, 1991. Temporal competence for transformation of Lycopersicon esculentum (L. Mill.) cotyledonsby Agrobacterium tumefaciens: relation to woundhealing and soluble plant factors. J. Exp. Bot., 42: 359-364.

33. Hohn, B., Z. Koukolikova Nicla, G. Bakkeren and N. Grmsley, 1989. Agrobacterium mediated gene transformation in Monocots and Dicots. Genome, 31: 987-991.

34. Zambryski, P., 1992. Chronicles from the Agrobacterium-plant cell DNA transfer story. Ann. Rev. Plant Physiol., 43: 465-490.

35. Mohiuddin, A.K.M., K. Harikrishna, M.K.U. Chowdhury, Z.C. Abdullah and S. Napis, 2001. Influence of Acetosyringone on Agrobacteriummediated transformation of cucumber (Cucumis sativus L.). Plant Tissue Cult., 10: 167-173.

36. Akama, K., H. Puchta and B. Hohn, 1995. Efficient Agrobacterium-mediated transformation of Arabidopsis thaliana using the bar gene as selectable marker. Plant Cell Rep., 14: 450-454.

37. Chen, W.P. and Z.K. Punja, 2002. Agrobacteriummediated transformation of American ginseng with a rice chitinase gene. Plant Cell Rep., 20: 10391045.
38. Pigeaire, A., D. Abernethy, P.M. Smith, K. Simpson, N. Fletcher, C.Y. Liu, C.A. Atkins and E. Cornish, 1997. Transformation of a grain legume (Lupinus angustrifolius L.) via Agrobacterium tumefaciens-mediated gene transfer to shoot apices. Mol. Breed., 3: 341-349.

39. D'Hallun, K., J. Botterman and W. DeGreef, 1990. Engineering of herbicide resistant alfalfa and evolution under field condition. Crop. Sci., 30: 866-871.

40. Schroeder, HE., A.H. Schotz, T. WardleyRichardson, D. Spencer and T.J.V. Higgins, 1993. Transformation and Regeneration of Two Cultivars of Pea (Pisum sativum L.). Mol. Biol. Gene. Reg., 101: 751-757.

41. Zhang, Z., A. Xing, P. Staswick and T. Clemente, 1999. The use of glufosinate as a selective agent in Agrobacterium-mediated transformation of soybean. Plant Cell Tissue Organ Cult., 56: 37-46.

42. Manickavasagam, M., A. Ganapathi, V.R. Anbazhagan, B. Sudhakar, N. Selvaraj, A. Vasudevan and S. Kasthurirengan, 2004. Agrobacterium-mediated genetic transformation and development of herbicide-resistant sugarcane (Saccharum species hybrids) using axillary buds. Plant Cell Rep., 23: 134-143.

43. Tachibana, K. and K. Kaneko, 1986. Development of a new herbicide, bialaphos. J. Pestic. Sci., 11: 297-304.

44. Altun, G., 2001. Genetic transformation of tobacco with Hs1 (Pro-1) gene and evaluation of Nematode resistance in transgenic plants. M.S. Dissertation, Middle East Technical University, Ankara, Turkey.

45. Ye, G.N., S.M. Colburn, S.W. Xu, R. Peter, T.J. Hajdukiewicz and J.M. Staub, 2003. Persistence of Unselected Transgenic DNA during a Plastid Transformation and Segregation Approach to Herbicide Resistance. Plant Physiol., 133: 402-410. 